\title{
Perbandingan Struktur Komunitas Mikroartropoda Tanah di Lahan Zona Aktif dan Pasif TPA Jatibarang Semarang
}

\author{
Elda Dheiva Amelinda, Rully Rahadian dan Mochamad Hadi \\ Departemen Biologi, Fakultas Sains dan Matematika, Universitas Diponegoro \\ Jalan. Prof. H. Soedharto, SH, Tembalang, Semarang, Jawa Tengah, Indonesia 50275 \\ Email: eldadheiva@gmail.com
}

\begin{abstract}
Microarthropods is one of the important components of soil biology which is abundant and varied. The purpose of this research is to compare the structure of microartropod soil community and to examine the influence of physicalchemical factors of the environment based on the dynamics of abundance of soil microartropods in the active zone and the passive zone of Jatibarang Landfill Landfill Semarang. This research was conducted at Jatibarang Landfill Zone of active zone and passive zone by using purposive sampling method. The results showed that the number of species and the number of microartropods in the active zone was higher than the passive zone. In the active zone found 2240 individual $/ \mathrm{m}^{2}$ soil microartropods consisting of 21 species and 17 families, whereas in the passive zone found 480 individual $/ \mathrm{m}^{2}$ soil microartropods consisting of 10 species and 9 families. The dominating families in both the active and the passive zones are Sciaridae and Cicadellidae. Environmental factors that affect the diversity of soil microartropods are ground water content, soil porosity, heavy metal content such as $\mathrm{Pb}, \mathrm{Cu}$, and $\mathrm{Zn}$; As well as the availability of organic matter in the soil.
\end{abstract}

Keyword: Community structure, soil microarthropods, heavy metals, Jatibarang landfill

\begin{abstract}
Abstrak
Mikroartropoda merupakan salah satu komponen penting biologi tanah yang jumlahnya melimpah dan beragam. Tujuan dari penelitian ini yaitu untuk membandingkan struktur komunitas mikroartropoda tanah serta mengkaji pengaruh faktor fisik-kimia lingkungan berdasarkan dinamika kelimpahan mikroartropoda tanah di zona aktif dan zona pasif lahan TPA Jatibarang Semarang. Penelitian ini dilakukan di lahan TPA Jatibarang zona aktif dan zona pasif dengan menggunakan metode purposive sampling. Hasil penelitian menunjukkan bahwa jumlah jenis dan jumlah individu mikroartropoda pada zona aktif lebih tinggi dibandingkan zona pasif. Di zona aktif didapati $2240 \mathrm{individu} / \mathrm{m}^{2}$ mikroartropoda tanah yang terdiri dari 21 spesies dan 17 famili, sedangkan di zona pasif didapati $480 \mathrm{individu} / \mathrm{m}^{2}$ mikroartropoda tanah yang terdiri dari 10 spesies dan 9 famili. Famili yang mendominasi di zona aktif maupun zona pasif adalah jenis Sciaridae dan Cicadellidae. Faktor lingkungan yang mempengaruhi keanekaragaman mikroartropoda tanah yaitu kadar air dalam tanah, porositas tanah, kandungan logam berat seperti $\mathrm{Pb}, \mathrm{Cu}$, dan $\mathrm{Zn}$; serta ketersediaan bahan organik dalam tanah.
\end{abstract}

Kata kunci: Struktur komunitas, mikroartropoda tanah, logam berat, TPA Jatibarang 


\section{PENDAHULUAN}

Pemantauan ekosistem lingkungan yang tercemar umumnya dilakukan dengan parameter fisik atau kimia, tetapi baru-baru ini pemantauan secara biologi menggunakan organisme tanah mulai mendapatkan perhatian luas. Menurut Suin (1997) hal ini dikarenakan organisme tanah bersifat sensitif terhadap perubahan yang terjadi di tanah dan jumlahnya melimpah. Sifat-sifat fisik dan kimia tanah selain berpengaruh langsung terhadap organisme tanah juga lebih cenderung menginformasikan keadaan tanah hanya pada waktu pengukuran (Suwondo, 2002).

Keadaan fauna tanah di suatu tempat dengan tempat yang lainnya berbeda. Kehidupan fauna tanah sangat tergantung pada habitatnya, karena keberadaan dan kepadatan populasi suatu jenis fauna tanah di suatu daerah sangat ditentukan oleh faktor lingkungan, yaitu lingkungan biotik dan lingkungan abiotik. Peran aktif fauna tanah, khususnya mesofauna tanah dalam menguraikan bahan organik dapat mempertahankan dan mengembalikan produktivitas tanah dengan didukung faktor lingkungan disekitarnya (Thamrin, 1992). Lingkungan terganggu atau terdegradasi pada umumnya memiliki fauna tanah yang mengalami penurunan komposisi jenis maupun kelimpahan yang disebabkan oleh penurunan atau hilangnya sejumlah spesies (Nuril dkk., 1999).

Studi dan penelitian di bidang ekologi dan lingkungan cukup banyak mengungkap tentang keanekaragaman (diversity) suatu komunitas. Hal ini disebabkan karena keanekargaman menunjukkan indikator kestabilan suatu komunitas. Kestabilan ini menunjukkan bahwa suatu komunitas akan relatif stabil walaupun banyak gangguan terhadap komunitas tersebut. Keanekaragaman spesies merupakan karakter komunitas yang penting untuk dikaji secara mendalam baik secara konsep maupun aplikasinya di lapangan (Dharmawan dkk, 2005). Keanekaragaman identik dengan kestabilan suatu ekosistem, yaitu jika keanekaragaman suatu ekosistem tinggi, maka kondisi ekosistem tersebut cenderung stabil (Odum, 1993).

Tempat Pembuangan Akhir (TPA) Jatibarang merupakan salah satu sumber limbah dan menjadi tempat pembuangan akhir sampah dari seluruh kota Semarang serta lokasinya dekat dengan pemukiman penduduk. Luas TPA sekitar 46,18 ha dan merupakan satu-satunya TPA yang aktif beroperasi dan menampung sampah seluruh wilayah Semarang. Luas lahan yang telah tertutupi sampah \pm 7 ha. Lahan TPA memiliki beberapa zona dengan perbedaan karakteristik setiap zona dimana lahan tersebut masih berfungsi sebagai tempat pembuangan sampah, terdapat aktivitas penimbunan sampah. Zona tersebut yaitu zona aktif yang dicirikan terdapat aktivitas penimbunan dan zona pasif yang tidak ada aktivitas pembuangan maupun penimbunan sampah dan telah tertutupi oleh soil cover.

Penelitian mengenai mikroartropoda tanah dapat membantu untuk mengetahui fungsinya di dalam tanah, serta menunjukkan keanekaragaman komunitas (Suhardjono, 1997). Analisis tanah tercemar dengan $\mathrm{Cu}, \mathrm{Zn}$ dan $\mathrm{Pb}$ telah mengungkapkan bahwa mikroartropoda telah berhasil digunakan untuk mengevaluasi kualitas tanah. Hal ini terbukti dari hasil pengukuran $\mathrm{pH}$ dan perhitungan rasio $\mathrm{C} / \mathrm{N}$ tanah dan kandungan logam berat di lingkungan tersebut (Straalen $e t$ al, 1997). Berdasarkan uraian di atas maka identifikasi kelimpahan serta keanekaragaman jenis merupakan hal yang penting, sehingga dapat diketahui peran organisme terhadap lingkungan (Lavelle et al, 2006).

Tanah merupakan bagian dari siklus logam berat. Pembuangan limbah ke tanah apabila melebihi kemampuan tanah dalam mencerna limbah akan mengakibatkan pencemaran tanah. Jenis limbah yang potensial merusak lingkungan hidup adalah limbah yang termasuk dalam Bahan Beracun Berbahaya (B3) yang di dalamnya terdapat logam logam berat. Menurut Arnold (1990 dalam Subowo et al. 1995), logam berat adalah unsur logam yang mempunyai massa jenis lebih besar dari $5 \mathrm{~g} / \mathrm{cm} 3$, antara lain $\mathrm{Cd}, \mathrm{Hg}, \mathrm{Pb}, \mathrm{Zn}$, dan $\mathrm{Ni}$. Logam berat $\mathrm{Cd}, \mathrm{Hg}$, dan $\mathrm{Pb}$. Kandungan logam berat didalam tanah secara alamiah sangat rendah, kecuali tanah tersebut sudah tercemar dan terdapat ukuran batas kritis logam berat pencemar dalam tanah (Tabel.1).

Tabel 1. Batas kritis unsur-unsur logam berat dalam tanah

\begin{tabular}{cc}
\hline Unsur logam berat & $\begin{array}{c}\text { Batas kritis } \\
(\mathrm{ppm})\end{array}$ \\
\hline $\mathrm{Pb}^{1}$ & 100 \\
$\mathrm{Cd}^{1}$ & 0,50 \\
$\mathrm{Co}^{1}$ & 10 \\
$\mathrm{Cr}^{1}$ & 2,5 \\
$\mathrm{Ni}^{1}$ & 20 \\
$\mathrm{Cu}^{1}$ & $60-125$ \\
$\mathrm{Mn}^{1}$ & 1500 \\
$\mathrm{Zn}^{1}$ & 70 \\
$\mathrm{Hg}^{2}$ & 420 \\
\hline
\end{tabular}

1. Ministry of State for Population and Environment of Indonesia, and Dalhousie University, Canada (1992).

2. U.S Environmental Protection Agency Washington (1993). 
Penentuan struktur komunitas menambahkan informasi penting tentang status tanah serta kelimpahan, penyebaran dan populasi mikrofauna (protozoa, nematoda) dan mikroartropoda bergantung pada konsentrasi kandungan logam berat di dalam tanah. Struktur komunitas mikroartropoda dapat mencerminkan faktor lingkungan yang berpengaruh terhadap tanah, maka penelitian ini dilakukan untuk mengkaji pengaruh faktor fisik-kimia lingkungan terhadap struktur komunitas mikroartropoda tanah pada zona aktif dan zona pasif di lahan Tempat Pembuangan Akhir Jatibarang Kota Semarang.

\section{BAHAN DAN METODE Waktu dan Lokasi Penelitian}

Penelitian ini dilakukan pada bulan September 2016 di zona aktif dan zona pasif lahan Tempat Pembuangan Akhir (TPA) Jatibarang Kota Semarang. Proses ekstraksi dan identifikasi dilakukan di Laboratorium Ekologi \& Biosistematik, Jurusan Biologi, FSM,UNDIP. Proses analisis fisik-kimia tanah dilakukan di Laboratorium Teknik Lingkungan dan Mekanika Tanah, FT, UNDIP.

\section{Bahan dan Alat}

Bahan dalam penelitian adalah alkohol 70\% dan sampel tanah. Alat yang digunakan antara lain GPS, termometer udara, termometer tanah, higrometer, luxmeter, soil pH tester, sekop kecil, kantong kain, botol sampel, kertas label, corong Barlese, mikroskop, cawan petri, gelas arloji, gelas benda, pipet, jarum pentul, alat tulis dan buku identifikasi serta kamera.

\section{Cara Kerja}

a. Penentuan Stasiun dan Pengambilan Sampel

Penentuan stasiun dilakukan secara purposive dengan menentukan kriteria lahan berdasarkan Penentuan lokasi penelitian berdasarkan perbedaan penggunaan lahan, yaitu zona aktif dan zona pasif.

Sebelum pengambilan sampel, terlebih dulu dibuat batasan area sampling lalu dibuat petak diagonal $5 \times 5 \mathrm{~m}^{2}$. Titik pengambilan sampel yaitu pada tiap ujung petak dan bagian tengah petak, sehingga ada 5 titik sampel.

Setiap titik sampel diambil dua sampel tanah untuk identifikasi mikroartropoda dan analisis fisik-kimia tanah. Sampel tanah diambil menggunakan sekop kecil seluas 10 x $10 \mathrm{~cm}$ (kedalaman $10 \mathrm{~cm}$ dan diameter $10 \mathrm{~cm}$ ). Selanjutnya tanah segera dimasukkan ke dalam kantong kain untuk menjaga agar fauna tetap hidup sampai sebelum diekstraksi.

b. Ekstraksi dan Identifikasi

Ekstraksi mikroartropoda dilakukan menggunakan corong Barlese hasil modifikasi.
Sampel tanah selanjutnya dimasukkan ke dalam corong yang dilapisi jaring jala, kemudian disinari lampu bohlam 40 watt. Bagian bawah corong diberi perangkap berupa botol berisi alkohol $70 \%$ sebagai larutan fiksatif untuk mengawetkan mikroarthropoda. Proses ekstraksi dilakukan selama 7 x 24 jam. Proses identifikasi dan pengelompokkan famili dilakukan dengan mengamati morfologi mikroartropoda menggunakan mikroskop dan buku identifikasi.

c. Analisis Fisik-Kimia Tanah

Analisis fisik-kimia tanah yang dilakukan meliputi $\mathrm{pH}$, kelembaban, suhu, tekstur tanah, porositas tanah, aerasi tanah, kandungan bahan organik, serta analisis kandungan logam berat $(\mathrm{Pb}$, $\mathrm{Cd}, \mathrm{Cu}, \mathrm{Zn}, \mathrm{Hg}$ ). Analisis $\mathrm{pH}$, suhu dan kelembaban tanah dilakukan saat pengambilan sampel di lapangan. Pengukuran dilakukan sebanyak 3 kali ulangan. Analisis kandungan bahan organik, serta kandungan logam berat $(\mathrm{Pb}$, $\mathrm{Cd}, \mathrm{Cu}, \mathrm{Zn}, \mathrm{Hg}$ ) dilakukan di Laboratorium Teknik Lingkungan, FT UNDIP. Sedangkan analisis tekstur tanah, kandungan air tanah dan porositas tanah dilakukan di Laboratorium Mekanika Tanah, Jurusan Teknik Sipil, FT UNDIP.

d. Analisis Data

Analisis data menggunakan indeks kelimpahan relatif, indeks keanekaragaman Shannon-Wiener, indeks kemerataan, dan indeks kesamaan Sorensen.

\section{HASIL DAN PEMBAHASAN}

Hasil penelitian di lahan TPA Jatibarang didapatkan 480-2240 individu/ $\mathrm{m}^{2}$ dari 8 ordo, 18 famili, dan 29 spesies. Berdasarkan taksa famili mikroatropoda tanah yang paling banyak ditemukan di zona aktif yaitu Sciaridae, sedangkan di zona pasif yaitu Liopteridae (Tabel 2). Mikroartropoda yang ditemukan di zona aktif lebih melimpah dibandingkan di zona pasif, dimana di zona aktif ditemukan sejumlah 2240 individu/ $\mathrm{m}^{2}$ mikroartropoda tanah yang terdiri dari 17 famili, sedangkan di zona pasif ditemukan 480 individu $/ \mathrm{m}^{2}$ mikroartropoda tanah dari 9 famili (Tabel 2).

Kepadatan mikroartropoda tanah di zona aktif lebih tinggi dibandingkan dengan zona pasif (Tabel 2). Ordo Diptera memiliki kepadatan individu paling tinggi di antara ordo yang lainnya, dan famili paling tinggi yaitu terdiri dari 17 famili dengan total 800 individu $/ \mathrm{m}^{2}$ individu dan pada famili Sciaridae sebanyak 600 individu $/ \mathrm{m}^{2}$, kepadatan dari famili Cicadellidae sebanyak 360 individu $/ \mathrm{m}^{2}$ serta Staphylinidae, Tiniedae, Aderidae, Scolytidae, Apoidae, Liopteridae, Poduromorpha, Cucujidae, Antomyiidae, Cecidomyiidae, Ceratopogonidae, Ephydridae, 
Hebridae, Formicidae Thynnidae dan Thiripidae dengan kepadatan berkisar antara $40-120$ individu $/ \mathrm{m}^{2}$ (Tabel 2).

Kepadatan mikroartropoda tanah yang lainnya di zona pasif berkisar antara 20-60 individu $/ \mathrm{m}^{2}$ (Tabel 2). Ordo Hymenoptera memiliki keanekaragaman individu tertinggi di antara ordo yang lainnya, dari famili Liopteridae dengan total 140 individu/ $\mathrm{m}^{2}$, diikuti oleh famili Cicadellidae dan Sciaridae sebanyak 80 individu $/ \mathrm{m}^{2}$.

Zona aktif dibandingkan dengan zona pasif memiliki perbedaan kepadatan individu apabila dilihat dari komposisi famili yang ditemukan. Hasil perolehan data tersebut dapat menunjukkan adanya pengaruh faktor abiotik di TPA terhadap kehadiran mikroartropoda tanah di habitat tersebut.

Tingginya kepadatan Sciaridae (Diptera) di zona aktif kemungkinan karena banyaknya sampah organik di zona tersebut yang sangat disukai oleh larva diptera saprofagus. Menurut Brown (1978), Diptera berperan dalam kesuburan tanah dan mempercepat proses pembentukan humus. Aktivitas makan dari larva diptera saprofagus membantu fragmentasi materi organik lebih banyak.

Tabel 2. Kepadatan (K), kekayaan spesies (S), kelimpahan (Di) mikroartropoda tanah di zona aktif dan zona pasif TPA Jatibarang Semarang

\begin{tabular}{|c|c|c|c|c|c|c|}
\hline \multicolumn{3}{|c|}{ Taksa } & \multicolumn{2}{|c|}{ Zona Aktif } & \multicolumn{2}{|c|}{ Zona Pasif } \\
\hline Ordo & Famili & Spesies & Indv/ $\mathrm{m}^{2}$ & Di $(\%)$ & $\mathrm{Indv} / \mathrm{m}^{2}$ & $\operatorname{Di}(\%)$ \\
\hline Collembola & Poduromorpha & Sp1 & 40 & $1,78^{r}$ & 0 & 0 \\
\hline \multirow[t]{8}{*}{ Coleoptera } & Aderidae & $\mathrm{Sp} 2$ & 0 & 0 & 60 & $12,5^{\mathrm{d}}$ \\
\hline & & Sp3 & 120 & $5,35^{\text {sd }}$ & 0 & 0 \\
\hline & Cucujidae & Sp4 & 40 & $1,78^{r}$ & 0 & 0 \\
\hline & Scolytidae & Sp5 & 0 & 0 & 20 & $4,16^{\text {sd }}$ \\
\hline & & Sp6 & 80 & $3,57^{\text {sd }}$ & 0 & 0 \\
\hline & Staphylinidae & Sp7 & 0 & 0 & 20 & $4,16^{\text {sd }}$ \\
\hline & & Sp8 & 240 & $10,71^{d}$ & 0 & 0 \\
\hline & & Sp9 & 40 & $1,78^{r}$ & 0 & 0 \\
\hline \multirow[t]{11}{*}{ Diptera } & Antomyiidae & Sp10 & 40 & $1,78^{r}$ & 0 & 0 \\
\hline & Cecidomyiidae & Sp11 & 40 & $1,78^{r}$ & 0 & 0 \\
\hline & Ceratopogonidae & $\mathrm{Sp} 12$ & 40 & $1,78^{\mathrm{r}}$ & 0 & 0 \\
\hline & & Sp13 & 40 & $1,78^{r}$ & 0 & 0 \\
\hline & Ephydridae & Sp14 & 40 & $1,78^{r}$ & 0 & 0 \\
\hline & & Sp15 & 0 & 0 & 20 & $4,16^{\text {sd }}$ \\
\hline & Sciaridae & Sp16 & 480 & $21,42^{d}$ & 0 & 0 \\
\hline & & Sp17 & 0 & 0 & 60 & $12,5^{\mathrm{d}}$ \\
\hline & & Sp18 & 0 & 0 & 20 & $4,16^{\text {sd }}$ \\
\hline & & Sp19 & 80 & $3,57^{\text {sd }}$ & 0 & 0 \\
\hline & & $\mathrm{Sp} 20$ & 40 & $1,78^{r}$ & 0 & 0 \\
\hline Hemiptera & Hebridae & $\mathrm{Sp} 21$ & 40 & $1,78^{r}$ & 0 & 0 \\
\hline Homoptera & Cicadellidae & Sp22 & 360 & $16,07^{\mathrm{d}}$ & 80 & $16,66^{\mathrm{d}}$ \\
\hline \multirow[t]{4}{*}{ Hymenoptera } & Apoidae & Sp23 & 80 & $3,57^{\text {sd }}$ & 0 & 0 \\
\hline & Formicidae & $\mathrm{Sp} 24$ & 40 & $1,78^{r}$ & 0 & 0 \\
\hline & Liopteridae & $\mathrm{Sp} 25$ & 80 & $3,57^{\text {sd }}$ & 140 & $29,16^{\mathrm{d}}$ \\
\hline & Thynnidae & $\mathrm{Sp} 26$ & 40 & $1,78^{r}$ & 0 & 0 \\
\hline \multirow[t]{2}{*}{ Lepidoptera } & Tineidae & $\mathrm{Sp} 27$ & 0 & 0 & 40 & $4,16^{\text {sd }}$ \\
\hline & & $\mathrm{Sp} 28$ & 240 & $10,71^{d}$ & 0 & 0 \\
\hline \multirow[t]{4}{*}{ Thysanoptera } & Thiripidae & Sp29 & 0 & 0 & 60 & $8,33^{\text {sd }}$ \\
\hline & Total Kepadatan & $(\mathrm{K})$ & 2240 & & 480 & \\
\hline & Jumlah Spesies & $(\mathrm{S})$ & \multirow{2}{*}{\multicolumn{2}{|c|}{$\begin{array}{l}21 \\
17\end{array}$}} & \multicolumn{2}{|c|}{10} \\
\hline & Jumlah Famili & & & & \multicolumn{2}{|c|}{9} \\
\hline
\end{tabular}

Kelimpahan relatif mikroartropoda di zona aktif maupun zona pasif TPA Jatibarang menunjukkan hasil bervariasi. Kelimpahan relatif digunakan untuk menggambarkan dominansi taksa dalam suatu habitat. Kategori kelimpahan relatif terbagi menjadi 5 yaitu dominan, subdominan, reseden, subreseden, dan sporadik (Rahadian,
2009). Mikroartropoda tanah yang memiliki nilai dominan di zona aktif antara lain Sciaridae (Sp16) 21,42\%, Cicadellidae (Sp22) 16,07\%, Staphylinidae (Sp8) 10,71\%, dan Tineidae (Sp28) $10,71 \%$, sedangkan mikroartropoda tanah yang memiliki nilai dominan di zona pasif antara lain Liopteridae (Sp25) 29,16\%, Cicadellidae (Sp22) 
16,66\%, Aderidae (Sp2) 12,5\%, dan Sciaridae (Sp17) 12,5\% (Tabel.3)

Tabel 3.Kepadatan, Jumlah Famili, dan Famili Dominan di Tiap Stasiun

\begin{tabular}{cccl}
\hline Stasiun & $\begin{array}{c}\text { Kepadatan } \\
\text { individu/m }\end{array}$ & $\begin{array}{c}\text { Jumlah } \\
\text { famili }\end{array}$ & $\begin{array}{c}\text { Famili } \\
\text { Dominan }\end{array}$ \\
\hline Zona Aktif & 2240 & 17 & $\begin{array}{l}\text { Sciaridae, } \\
\text { Cicadellidae, } \\
\text { Staphylinidae } \\
\text { dan Tineidae. }\end{array}$ \\
Zona Pasif & 480 & 9 & $\begin{array}{l}\text { Liopteridae, } \\
\text { Cicadellidae, } \\
\text { Aderidae, } \\
\text { dan } \\
\text { Sciaridae. }\end{array}$ \\
\hline
\end{tabular}

$\overline{* \text { Famili dominan adalah famili yang mempunyai lebih dari } 1}$ spesies dominan $(\mathrm{Di}>10 \%)$

Nilai kelimpahan relatif dipengaruhi oleh banyaknya taksa dan jumlah individu tiap taksa. Selain itu, kelimpahan relatif juga berkaitan dengan dominansi suatu taksa tertentu dalam ekosistem (Odum, 1998). Kelimpahan relatif akan bernilai tinggi (dominan) apabila jumlah individu suatu taksa memiliki jumlah yang banyak, sebaliknya akan bernilai rendah apabila jumlah indivdunya hanya sedikit. Jumlah individu suatu taksa apabila sangat melimpah dan distribusinya tidak merata dapat menimbulkan dominansi bagi taksa yang lain.

Di zona aktif ditemukan mikroartropoda tanah dari Ordo Diptera dengan nilai dominan tertinggi dan jumlah yang melimpah (Tabel.3). Keberadaan famili Sciaridae (Diptera) di zona aktif dengan menenpati nilai kelimpahan tertinggi dikarenakan dengan ketersediaan bahan organik sebagai sumber energi makanan. Hal ini sesuai dengan pernyataan Frouz (1994), bahwa beberapa spesies tanah ordo Diptera memainkan peran penting dalam dekomposisi bahan organik dan unsur hara.

Di zona pasif ditemukan mikroartropoda tanah dari Ordo Hymenoptera dengan nilai dominan tertinggi dan jumlah yang melimpah (Tabel.3). Ditemukannya famili mikroartropoda tanah parasitoid dari ordo Hymenoptera dengan jumlah yang melimpah yaitu dari famili Liopteridae.

Nilai indeks keanekaragaman pada zona aktif $(2,59)$ dan zona pasif $(2,04)$ (Tabel ). Magguran (1987) menjelaskan bahwa indeks keanekaragaman yang berkisar antara 1,5 - 3,5 termasuk kategori sedang, jika melebihi 3,5 maka termasuk kategori tinggi. Indeks keanekaragaman pada kedua stasiun penelitian TPA Jatibarang termasuk kategori sedang. Tingkat keanekaragaman dengan kategori sedang, kemungkinan akibat dari perubahan kondisi lahan dan tekstur tanah, sehingga kehadiran mikroartropoda tanah tidak begitu beragam. Faktor abiotik seperti suhu, $\mathrm{pH}$, dan kelembaban tanah juga mempengaruhi keanekaragaman taksa mikroartropoda tanah. Nilai $\mathrm{pH}$ yang optimal bagi pertumbuhan mikroartropoda tanah antara 5 -7 (Straalen, 1998). Hal yang serupa diungkapkan oleh Suin (2006) bahwa kehadiran dan kepadatan populasi fauna tanah sangat ditentukan oleh faktor fisika - kimia tanah diantaranya tekstur tanah, suhu, kadar material organik, $\mathrm{pH}$, kadar air tanah dan material tanah

Tabel 4. Jumlah Spesies, Jumlah Famili, Indeks Keanekaragaman, dan Indeks Kemerataan, Tiap Stasiun serta Indeks Kesamaan Antar Stasiun

\begin{tabular}{lcc}
\hline \multicolumn{1}{c}{ Indeks } & Zona Aktif & Zona Pasif \\
\hline Jumlah spesies & 21 & 10 \\
Jumlah famili & 17 & 9 \\
Indeks keanekaragaman (H') & 2,59 & 2,04 \\
Indeks kemerataan (e) & 0,85 & 0,85 \\
Indeks kesamaan (IS) & \multicolumn{2}{c}{$12,90 \%$} \\
\hline
\end{tabular}

Secara statistik, keanekaragaman mikroartropoda tanah (uji t-Hutchinson) pada zona aktif dengan zona pasif menunjukkan hasil yang tidak signifikan. Pembuktian menggunakan uji tHutchison menunjukkan $t$ hitung $=0,110<4,221$ dibandingkan pada $t$ tabel dengan taraf signifikansi $\alpha$ 0,05. Hal ini menunjukkan bahwa keanekaragaman pada lahan zona aktif dan zona pasif tidak berbeda nyata. Keanekearagaman mikroartropoda tanah yang tidak berbeda nyata dimungkinkan karena habitat kedua stasiun tersebut tidak jauh berbeda dan masih pada kondisi geografis yang sama, sehingga taksa yang ditemukan pada masing-masing stasiun tidak jauh berbeda.

Indeks kemerataan pada zona aktif dan zona pasif memiliki tingkat kemerataan yang sama (Tabel.4), hal ini dikarenakan jumlah individu masing masing spesies mikroartropoda tanah memiliki sebaran yang hampir merata jika dibandingkan dengan jumlah individu masingmasing mikroartropoda tanah. Pada zona aktif dan zona pasif, terdapat famili yang nilai kelimpahannya dominan dan mempunyai jumlah individu yang tinggi, yaitu famili Cicadellidae (Tabel.2) Tingginya nilai indeks kemerataan pada kedua zona mengindikasikan bahwa terdapat dominasi jenis dari famili tertentu terhadap jenis yang lainnya. Tidak adanya dominansi jenis dari famili tertentu dikarenakan ketersediaan nutrisi yang cukup bagi kebutuhan mikroartropoda tanah. Menurut Odum (1993), keanekaragaman yang 
tinggi dapat ditentukan oleh tingkat kelimpahan dan kemerataan, apabila kelimpahan tinggi sedangkan tingkat kemerataan rendah maka menurunkan nilai keanekaragaman, walaupun jumlah jenisnya banyak tetapi jika sebaran tidak merata maka nilai keanekaragamannya rendah. Keanekaragaman mikroartropoda tanah di zona aktif dan zona pasif berbanding lurus dengan kemerataan dan kelimpahan taksa mikroartropoda tanah.

Hasil indeks kesamaan jenis antara zona aktif dan zona pasif yaitu 12,90\% (Tabel.4). Hasil indeks ini termasuk kedalam kategori rendah (Michael, 1984) kesamaan jenis mikroartropoda tanah yang rendah menunjukkan kedua zona lahan memiliki struktur komunitas karakteristik ekosistem yang berbeda. Perbedaan karakteristik jenis lahan pada zona aktif dan zona pasif menunjukkan bahwa faktor lingkungan yang ada pada kedua lahan cenderung berbeda.

Faktor abiotik yang diukur dibagi menjadi dua faktor, yaitu faktor fisik dan kimia. Faktor fisik diukur diantaranya suhu, kelembaban, dan tekstur tanah, kandungan air tanah, serta porositas tanah. Faktor kimianya yaitu $\mathrm{pH}$, kandungan bahan organik, serta analisis kandungan logam berat $(\mathrm{Pb}$, $\mathrm{Cd}, \mathrm{Cu}, \mathrm{Zn}, \mathrm{Hg}$ ).

Analisis fisik tanah. Suhu tanah pada zona aktif dan zona pasif adalah $31^{\circ} \mathrm{C}$ dan $36,3^{\circ} \mathrm{C}$. Suhu tanah di zona aktif menunjukan nilai yang lebih rendah dibandingkan dibandingkan dengan suhu tanah di zona pasif (Tabel.5). Menurut Syahribulan (2001), keberadaan fauna tanah di suatu habitat dipengaruhi oleh sejumlah faktor lingkungan, diantaranya kemampuan menyebar, seleksi habitat, suhu, dan kelembaban udara, kelembaban tanah, cahaya, curah hujan dan ketersediaan makanan.

Zona aktif kondisi lahannya lebih lembab dibandingkan zona pasif. Kelembaban merupakan faktor penting bagi mikroartropoda tanah. Kelembaban tanah merupakan jumlah air yang tersimpan di dalam pori-pori tanah. Keadaan tanah yang lembab menyebabkan beberapa jenis mikroartropoda tanah, seperti Diptera bermigrasi ke lapisan yang lebih dalam mencari kondisi yang lebih sesuai dan atau fauna tersebut berada dalam tahap pradewasa/dewasa sehingga lebih aktif bergerak. (Suhardjono \& Adisoemarto,1997).

Tabel 5. Parameter fisik tanah di zona aktif dan zona pasif TPA Jatibarang Semarang

\begin{tabular}{lrr}
\hline \multicolumn{1}{c}{ Parameter Faktor Fisik } & Zona Aktif & Zona Pasif \\
\hline pH Tanah & $6,76 \pm 0,25$ & $6,90 \pm 0,00$ \\
Suhu Tanah & $31,00 \pm 1,00$ & $36,30 \pm 1,52$ \\
Kelembaban Tanah & $100 \pm 0,00$ & $80,00 \pm 8,60$ \\
Intensitas Cahaya & $634,00 \pm 87,78$ & $604,30 \pm 29,10$ \\
Kadar Air (w) \% & $40,50 \pm 0,94$ & $25,12 \pm 0,20$ \\
Tekstur Tanah \% & & \\
$-\quad$ Kerikil & $14,41 \pm 0,67$ & 0,00 \\
$-\quad$ Pasir Kasar & $18,65 \pm 2,08$ & $5,35 \pm 0,58$ \\
$-\quad$ Pasir Halus & $29,65 \pm 0,97$ & $12,47 \pm 1,32$ \\
$-\quad$ Lanau & $37,27 \pm 3,38$ & $82,23 \pm 1,85$ \\
$-\quad$ Lempung & 0,00 & 0,00 \\
Porositas (n) \% & $56,18 \pm 0,52$ & $49,85 \pm 0,17$ \\
\hline
\end{tabular}

Struktur tanah dipengaruhi oleh tekstur tanah, bahan organik dan fauna tanah. Tekstur tanah yang dominan adalah pasir dan lanau. Sifat fisik tanah berperan dalam hal kemampuan menyimpan air, umumnya tanah dengan kandungan pasir tinggi kapasitas menyimpan air rendah. Sehingga apabila terdapat tanaman, tanaman tersebut akan segera menghabiskan persediaan air dan akan menjadi kering lebih cepat daripada tanaman yang tumbuh pada tanah berlempung. Kandungan pasir dan lanau yang lebih dominan dibandingkan gravel dan lempung dapat memungkinkan lapisan tanah mudah untuk luruh dan rentan kehilangan top soil dan sub soilnya.Suin (1988) menyebutkan bahwa kehadiran dan kepadatan populasi fauna tanah juga sangat ditentukan oleh faktor fisika tanah, diantaranya tekstur tanah, suhu tanah, dan kadar air tanah.

Porositas tanah pada zona aktif sebesar 56,18 $\%$ dan zona pasif sebesar 49,85\%. (Tabel 5.). Porositas tanah adalah ruang volume seluruh poripori makro dan mikro dalam tanah yang dinyatakan dalam persentase volume tanah di lapangan. Tanah berpasir mempunyai porositas kurang dari $50 \%$, dengan jumlah pori-pori makro lebih besar daripada pori-pori mikro, bersifat mudah merembes air dan gerakan udara di dalam tanah menjadi lebih lancar. Sebaliknya berliat mempunyai porositas lebih dari 50\%. Jumlah poripori mikro lebih besar dan bersifat mudah menangkap air hujan, tetapi sulit merembeskan air dan gerakan udara lebih terbatas. Porositas sangat 
dipengaruhi oleh tekstur tanah, struktur tanah, kedalaman tanah, dan pengolahan tanah.

Faktor kimia tanah yang dianalisis di laboratorium berupa logam berat yaitu $\mathrm{Pb}, \mathrm{Cd}, \mathrm{Cu}$, $\mathrm{Zn}$ dan $\mathrm{Hg}$, serta kandungan bahan organik. Masing-masing nilai logam berat yang terkandung dalam tanah di zona aktif cenderung lebih rendah dibandingkan zona pasif kecuali $\mathrm{Hg}$ serta kandungan bahan organik (Tabel 6). Kandungan logam berat yang terdapat di zona aktif maupun pasif masih berada dalam batas kritis unsur logam berat di dalam tanah, yang diacu dari U.S. Environmental Protection Agency Washington (1993) (Tabel 1). Sedangkan berdasarkan kandungan logam berat pada tanah secara alamiah beberapa logam berat yang berada di zona pasif memiliki nilai yang lebih tinggi dibandingkan dengan standar optimum kandungan logam berat di dalam tanah diantaranya $\mathrm{Cu}, \mathrm{Zn}$ dan $\mathrm{Hg}$ (Tabel 6).

Tabel 6. Parameter kandungan logam berat tanah di zona aktif dan zona pasif TPA Jatibarang Semarang (rerata \pm Sdev, $\mathrm{n}=3$ )

\begin{tabular}{crrrrrrr}
\hline Parameter Faktor Kimia & \multicolumn{3}{c}{ Zona } & \multicolumn{3}{c}{ Zktif } & \multicolumn{3}{c}{ Zona Pasif } \\
\hline $\mathrm{Pb}(\mathrm{g} / \mathrm{g})$ & 3,92 & \pm & 0 & & 7,26 & \pm & 0,11 \\
$\mathrm{Cd}(\mathrm{g} / \mathrm{g})$ & $<0,01$ & \pm & 0 & & $<0,03$ & \pm & 0,1 \\
$\mathrm{Cu}(\mathrm{g} / \mathrm{g})$ & $<0,005$ & \pm & 0 & & 30,1 & \pm & 0,1 \\
$\mathrm{Zn}(\mathrm{g} / \mathrm{g})$ & $<0,05$ & \pm & 0 & & 234 & \pm & 2,9 \\
$\mathrm{Hg}(\mathrm{g} / \mathrm{g})$ & 1,08 & \pm & 0 & & 0,87 & \pm & 1,35 \\
Bahan organik $(\%)$ & 5,3 & \pm & 0 & & 4,87 & \pm & 0,16 \\
\hline
\end{tabular}

Karakteristik logam berat yang lebih mudah terurai ada kaitannya dengan keberadaan mikroartropoda tanah maupun kadar air yang ada di masing-masing zona. Hal tersebut sesuai dengan pernyataan Suhariyono (2015) bahwa bentuk senyawa ikatan unsur-unsur kimia (termasuk logam berat) di dalam tanah mempunyai sifat kimia yang berbeda beda pula, termasuk daya larutnya di dalam air. Keberadaan mikroartropoda tanah di zona aktif sebanyak $2240 \mathrm{individu} / \mathrm{m}^{2}$ sedangkan di zona pasif sebanyak 480 individu $/ \mathrm{m}^{2}$, artinya mikrortropoda tanah di zona aktif lebih melimpah, sedangkan kadar air di zona aktif (40,50\%) memiliki nilai lebih tinggi dibandingkan zona pasif $(25,12)$. Hal tersebut ada hubungannya dengan mikroorganisme di dalam tanah, adanya degradasi oleh mikroorganisme dapat merubah senyawa logam berat dalam bentuk immobile menjadi mobile dan menyebabkan logam berat larut dalam air.

Kepadatan total, serta struktur komunitas dari mikroartropoda dapat berubah sehubungan dengan pencemaran logam tanah. Sesuai dengan hasil penelitian Gillet dan Ponge (2003) mengemukakan bahwa toksisitas logam berat pada tanah berpengaruh terhadap struktur komunitas mikroartropoda tanah. Total kepadatan dari mikroartropoda tanah dipengaruhi oleh toksisitas tanah dan pentingnya kandungan bahan organik dalam tanah untuk pengembangan mikroartropoda sebagai bioindikator tanah. Seperti yang diungkapkan oleh Neher et al. (2012), mikrofauna tanah tergantung pada dekomposisi organik residu yang tersedia di dalam tanah

\section{KESIMPULAN}

Zona aktif memiliki mikroartropoda tanah yang lebih melimpah (2240 individu/ $\mathrm{m}^{2}$ ) dan beragam (21 spesies dari 17 famili) dibandingkan di zona pasif yang hanya memiliki kelimpahan 480 individu $/ \mathrm{m}^{2}$ yang terdiri dari 10 spesies dari 9 famili. Famili Sciaridae ditemukan paling dominan di zona aktif, sedangkan di zona pasif Famili Liopteridae merupakan yang paling dominan. Secara statistik tidak ditemukan perbedaan secara nyata antara keanekaragaman mikroartropoda tanah di zona aktif $\left(H^{\prime}=2,59\right)$ dan zona pasif $\left(H^{\prime}=2,04\right)$. Kesamaan jenis mikroartropoda tanah di zona aktif dan zona pasif sangat rendah, yang mengindikasikan kedua zona tersebut berbeda secara komposisi jenis mikroartropoda tanah. Kepadatan dan kelimpahan mikroartropoda tanah berbanding lurus dengan faktor fisik kimia lingkungan seperti kadar air, porositas tanah, serta bahan organik dan berbanding terbalik dengan kandungan logam berat $\mathrm{Pb}, \mathrm{Cu}$ dan $\mathrm{Zn}$.

\section{UCAPAN TERIMA KASIH}

Terima kasih untuk Psn Masruri S.S, Dwiyani Anjar Martitik, Ana Rita Erviana, Anilda Yuniar dan Putri Yogantari selaku Tim Mikroartropoda yang senantiasa membantu, menyemangati, dan ikut serta dalam pembuatan jurnal ini. 


\section{DAFTAR PUSTAKA}

Brown. A.L. 1978. Ecology of Soil Organism. Heinemann Educational Books. London.

Dharmawan, A. 2005. Ekologi Hewan. UM-Press. Malang

EPA (U.S. Environmental Protection Agency). 1993. Report to Congress: Fundamental and Applied Research at the Environmental Protection Agency. EPA/600/R-93/038. Office of Research and Development, U.S. Environmental Protection Agency, Washington, DC.

Frouz J., 1994. Changes In The Terrestrial Chironomid Community (Diptera, Chironomidae) During Secondary Succession In Old Fields. Pedobiologia 38(4): 334-343.

Lavelle, P., T. Decaens, M. Aubert, S. Barot, M. Blouin, F. Bureau, P.Margerie, P. Mora, \& J.P. Rossi. 2006. Soil Invertebrates and Ecosystem Services. European Journal of Soil Ecology (42) : S3-S15.

Michael, P. 1995. Metode Ekologi untuk Penyelidikan Ladang dan Laboratorium. Alih Bahasa: Yanti R. Koestoer. Universitas Indonesia Press, Jakarta. Hal 25-43, 121122.

Ministry of State for Population and Environment Republic of Indonesia and Dalhousie University Canada. 1992. Environmental Management in Indonesia. Report on Soil Quality Standards for Indonesia (interim report). (Tidak dipublikasikan).

Neher, D.A., Weicht, T.R., Barbercheck, M.E. 2012. Linking invertebrate communities to decomposition rate and nitrogen availability in pine forest soils. Appl. Soil Ecol. 54, 14 23.

Nuril H., B Paul Naiola, E. Sambas, F. Syarif, M. Sudiana, J.S Rahajoe, Suciatmih, T. Juhaeti \& Y Soehardjono. Perubahan Bioekofisik Lahan Bekas Penambangan Emas Di Jampang Dan Metoda Pendekatannya Untuk Upaya Reklamasi. Laporan Teknik Proyek Penelitian, Pengembangan Dan Pendayagunaan Potensi Wilayah Tahun 1998/1999. Puslitbang Biologi LIPI Bogor.

Odum, E.P. 1993. Dasar-Dasar Ekologi. Edisi ketiga . Gajah Mada University Press, Jogjakarta.
Ponge, J. F., Dubs, F., Gillet, S., Sousa, J. P., \& Lavelle, P. 2003. Decreased biodiversity in soil springtail communities: The importance of dispersal and landuse history inheterogeneous landscapes. Soil Biology \& Biochemistry, 38,1158-1161.

Rahadian, R. 2009. Structure of Collembola Community and it's Nutrient Mineralization as Affected by Application of Different Organic Manures and Effective Microorganism. Dissertation. University of The Phillippines. Los Banos.

Suhardjono, Y.R. \& Adisoemarto. 1997. Artropoda Tanah: Artinya Bagi Tanah. Makalah pada Kongres dan Simposium Entomologi V Bandung 24-26 Juni 1997. Hal:10.

Suhariyono, Gatot. Y.Menry. 2015. Analisis Logam Berat Dalam Debu Udara Daerah Pemukiman Penduduk Di Sekitar Pabrik Semen, Citeureup Bogor. Puslitbang Keselamatan Radiasi dan Biomedika Nuklir. Puslitbang Teknologi Isotop dan Radiasi. Seminar APISORA P3TIR BATAN.

Straalen, V.N.M., J.H. M.Schobben, \& R.G.M. de Goede, Population consequences of cadmium toxicity in soil microarthropods, Ecotox. Environ. Safety 17 (1989) 190-204.

Subowo, Mulyadi, S. Widodo, dan Asep Nugraha. 1999. Status dan Penyebaran Pb, Cd, dan Pestisida pada Lahan Sawah Intensifikasi di Pinggir Jalan Raya. Prosiding. Bidang Kimia dan Bioteknologi Tanah, Puslittanak, Bogor.

Suin, N.M. 2006. Ekologi Hewan Tanah. Bumi Aksara: Jakarta.

Suwondo. 2002. Komposisi dan Keanekaragaman Mikroartropoda Tanah Sebagai Bioindikator Karakteristik Biologi pada Tanah Gambut. 2-9.

Syahribulan. 2001. Kumpulan Serangga pada Komunitas Teh Camellia sinensis (L.) . Thesis. Magister Biologi Bidang Entomologi Program Pasca Sarjana Institut Teknologi Bandung. (Tidak dipublikasikan).

Thamrin, M.dan Hanafi, H, 1992. "Peranan mulsa sisa tanaman terhadap konservasi lengas tanah pada system budidaya tanaman semusim di lahan kering". Prosiding Seminar Hasil Penelitian. P3HTA: 5-12 
Perbandingan Struktur Komunitas Mikroartropoda 
Elda Dheiva Amelinda, Rully Rahadian dan Mochamad Hadi 
Bioma, Desember 2017

p ISSN: 1410-8801

Vol. 19, No. 2, Hal. 141-149

e ISSN: 2598-2370 